\title{
Uji Diagnostik CD64 Netrofil untuk Sepsis pada Anak dengan Systemic Inflammatory Response Syndrome
}

Herlina, ${ }^{*}$ Mayetti, ${ }^{*}$ Husna Yetti**

*Departemen Ilmu Kesehatan Anak, **Departemen Ilmu Kesehatan Masyarakat Fakultas Kedokteran Universitas Andalas/RSUP Dr. M. Djamil, Padang

Latar belakang. Sepsis merupakan salah satu penyebab utama mortalitas dan morbiditas pada anak. Diagnosis dini sepsis sangat penting untuk menghindari keterlambatan atau overtreatment pemberian antibiotik. Kultur darah memerlukan waktu yang lama sehingga dibutuhkan suatu marker yang bisa menentukan diagnosis sepsis secara dini.

Tujuan. Penelitian ini bertujuan untuk mengetahui peranan CD64 netrofil sebagai salah satu marker untuk deteksi dini sepsis.

Metode. Penelitian cross sectional dilakukan di IGD RS Dr. M. Djamil Padang. Dilakukan pemeriksaan index CD64 netrofil dan kultur bakteri darah sebagai baku emas pada anak dengan systemic inflammatory response syndrome (SIRS). Analisis stastistik dilakukan untuk menetapkan cut off point index CD64 netrofil untuk diagnosis sepsis.

Hasil. Rerata index CD64 netrofil lebih tinggi pada kultur bakteri darah yang positif. CD64 netrofil memiliki sensitivitas 95,8\%, spesifisitas $81,6 \%$, nilai prediksi positif 76,7\%, dan nilai prediksi negatif $96,9 \%$ dengan penetapan cut-off point 1,5 . Pada penelitian ini didapatkan nilai cut off point 1,49 .

Kesimpulan. Indeks CD64 netrofil dapat digunakan sebagai parameter diagnostik pada sepsis. Nilai cut-offpoint index CD64 netrofil yang direkomendasikan sebagai batasan sepsis pada anak dengan SIRS adalah 1,49 atau 1,5. Sari Pediatri 2018;20(2):79-84

Kata kunci: CD64 netrofil, kultur bakteri darah, SIRS, sepsis

\section{Diagnostic Test of Neutrophil CD64 for Sepsis in Children with Systemic Inflammatory Response Syndrome}

Herlina, ${ }^{*}$ Mayetti, ${ }^{*}$ Husna Yetti**

Background. Sepsis is one of the major causes of mortality and morbidity in children. Early diagnosis of sepsis is essential for preventing delayed or overtreatment. Blood cultures for definitive diagnosis of sepsis require a long time, a marker is needed to determine early diagnosis of sepsis.

Objective. To know the role of CD64 neutrophil as marker for early detection of sepsis.

Methods.A cross-sectional study conducted in Emergency Room Dr. M. Djamil Hospital Padang. CD64 neutrophil index and blood bacterial culture as gold standard were examined in children with SIRS. Statistical analytic was done to determine cut off point of CD64 neutrophil index.

Results. CD64 neutrophil has sensitivity $95,8 \%$, specificity $81,6 \%$, positive prediction value $76,7 \%$ and negative prediction value $96,9 \%$ based on determination of cut-off point 1,5. The average CD64 neutrophil index was higher in positive blood bacterial cultures. Cut off point of CD64 neutrophil index based on this study was 1,49.

Conclusions. The neutrophil CD64 index can be used as a diagnostic parameter in sepsis. The recommended cut-off point of CD64 neutrophil index for sepsis diagnosis in children with SIRS was 1,49 or 1,5. Sari Pedíatri 2018;20(2):79-84

Keywords: CD64 neutrophil, bacterial blood culture, SIRS, sepsis

Alamat korespondensi: Husna Yetti. Departemen Ilmu Kesehatan Masyarakat Fakultas Kedokteran Universitas Andalas. Email: husnayetti@med.unand. ac.id 
S epsis adalah disfungsi organ yang mengancam kehidupan (life-threatening organ dysfunction) disebabkan oleh disregulasi imun terhadap infeksi. ${ }^{1,2}$ Sepsis menyebabkan mortalitas dan morbiditas pada anak di negara industri dan negara berkembang. ${ }^{3}$ Pevalensi sepsis $42,6 \%$ didapatkan pada anak yang dirawat di PICU. ${ }^{4}$ Meskipun dalam beberapa dekade terakhir menunjukkan perbaikan, sepsis masih merupakan penyebab utama kematian yang bervariasi di tiap negara (12\%-25\%)..$^{5-7}$

Diagnosis dini pada sepsis sangat penting agar tata laksana bisa diberikan segera sehingga angka kematian akibat sepsis berkurang. ${ }^{8}$ Pemberian awal terapi antibiotik yang sesuai telah terbukti mengurangi mortalitas 5 kali lipat pada pasien dengan syok septik. Sebaliknya, penggunaan antibiotik spektrum luas secara berlebihan akibat gejala yang tidak spesifik akan berdampak buruk mengingat risiko resistensi kuman. Selain itu, keterlambatan diagnosis sepsis menyebabkan waktu rawat di rumah sakit lebih lama dan berdampak pada peningkatan biaya dan risiko infeksi nosokomial. ${ }^{9}$

Dalam praktik klinik sering sulit dibedakan antara SIRS pada sepsis dengan SIRS non infeksi. Hal tersebut disebabkan karena manifestasi klinis yang sama dan kondisi SIRS non infeksi sering mencetuskan infeksi sekunder. Meskipun infeksi bisa diperkirakan dari awal, dibutuhkan waktu 3-5 hari atau lebih sebelum diagnosis definitif bisa dikonfirmasi atau disingkirkan dengan pemeriksaan laboratorium. Pemberian antibiotik penting untuk membedakan sepsis dengan SIRS yang lain. ${ }^{10}$

Kultur darah yang merupakan baku emas untuk diagnosis sepsis memiliki keterbatasan. Dibutuhkan waktu lama untuk menumbuhkan mikroorganisme pada media kultur. ${ }^{11,12}$ Berbagai pemeriksaan laboratorium telah digunakan untuk diagnosis sepsis, tetapi memiliki sensitifitas dan spesifisitas rendah. Kadar parameter tersebut rendah pada pasien sepsis yang mendapat kortikosteroid atau terapi sitotoksik dan tinggi pada keadaan SIRS non infeksi. ${ }^{11}$ Dibutuhkan suatu marker biokimia yang efektif, akurat, dan cepat untuk mendukung atau menyingkirkan diagnosis infeksi. ${ }^{13}$ Salah satu marker yang banyak diteliti saat ini adalah CD64 netrofil. CD64 netrofil adalah molekul yang diekspresikan pada permukaan netrofil saat terjadi proses infeksi. ${ }^{11,13-16}$

Penelitian ini bertujuan untuk mengetahui peranan CD64 netrofil sebagai biomarker diagnosis dini sepsis pada anak yang mengalami SIRS.

\section{Metode}

Penelitian ini adalah penelitian cross sectional yang dilakukan di IGD RSUP Dr. M. Djamil. Populasi penelitian adalah anak berusia 1 bulan sampai 14 tahun yang menderita SIRS yang masuk melalui IGD RS Dr. M. Djamil. Sampel penelitian adalah populasi penelitian yang memenuhi kriteria inklusi. Kriteria inklusi adalah semua penderita SIRS infeksi dan non infeksi yang bersedia mengikuti penelitian dengan menandatangani persetujuan (informed consent) oleh orang tua pasien. Kriteria eksklusi adalah anak dengan penyakit keganasan (limfoma, karsinoma, sarkoma, leukemia), penderita HIV/AIDS, penyakit auto imun (juvenile chronic arthritis, ankylosing spondylitis, psoriatic arthritis, systemic vasculitis, polymyalgia rheumatic, reiter disease, crohn disease). Pemilihan sampel dilakukan secara konsekutif sampling. Berdasarkan perhitungan jumlah sampel minimal 56, ditambah kemungkinan drop out sebesar $\pm 10 \%$ maka didapatkan jumlah sampel 62 orang. Penelitian ini telah mendapat izin dari komite etik Fakultas Kedokteran Unand, Padang.

CD64 netrofil diperiksa dengan metode flow citometry secara kuantitatif. Hasil pemeriksaan berupa index dengan hasil positif jika indeks CD64 netrofil $\geq 1,5$ dan negatif jika $<1,5$ (berdasarkan penelitian Grey). Pemeriksaan kultur darah sebagai gold standar dilakukan dengan mesin otomatis BacT/ALERT 3D Microbial Identification System dengan menggunakan medium BacT/ALERT FA yang merupakan media biakan darah aerobik.

Perbedaan index CD64 netrofil pada kultur darah positif dan negatif diuji dengan uji t tidak berpasangan dan dianggap bermakna jika nilai $\mathrm{p}<0,05$. Selanjutnya dilakukan uji diagnostik berupa sensitifitas, spesifisitas, nilai prediksi positif (NPP) dan nilai prediksi negatif (NPN). Cut off point index CD64 netrofil didapatkan berdasarkan analisis kurva ROC. Data diolah dengan menggunakan SPSS versi 15.

\section{Hasil}

Jumlah anak yang mengalami SIRS berusia 1 bulan sampai 14 tahun yang masuk melalui IGD RSUP Dr. M. Djamil Padang mulai bulan Maret 2017 sampai Juli 2017 berjumlah 98 anak. Karakteristik subjek penelitian tertera pada Tabel 1 . 
Tabel 1. Karakteristik subjek penelitian

\begin{tabular}{lcc}
\hline Karakteristik & $\mathrm{f}(\mathrm{n}=62)$ & $\%$ \\
\hline Jenis kelamin & & \\
$\quad$ Laki-laki & 31 & 50 \\
$\quad$ Perempuan & 31 & 50 \\
Kelompok usia & & \\
1 bulan -1 tahun & 21 & 34 \\
$>1-5$ tahun & 27 & 43 \\
$>5-14$ tahun & 14 & 23 \\
\hline
\end{tabular}

Berdasarkan karakteristik didapatkan jumlah anak perempuan sama dengan laki-laki. Usia $>1$ tahun -5 tahun merupakan kelompok yang terbanyak (43\%).

Tabel 2 menunjukkan rerata kadar CD64 netrofil pada awal masuk rumah sakit lebih tinggi bermakna pada kultur bakteri darah positif dibandingkan kultur darah negatif.

Pada Tabel 3 terlihat bahwa dari 24 kultur bakteri darah positif yang dapat dideteksi dengan CD64 netrofil sebanyak 23 sampel (sensitivitas 95,8\%). Pada 38 kultur bakteri darah yang negatif terdapat 31 sampel dengan kadar CD64 netrofil yang negatif (spesifisitas $81,6 \%)$.

Area under curve (AUC) untuk CD64 netrofil adalah 0,97 (95\% CI 0,951-1,007). Berdasarkan hasil analisis ROC didapatkan nilai cut-off point CD64 netrofil adalah 1,49 dengan sensitivitas $100 \%$ dan spesifisitas $76,3 \%$.

Pada Tabel 4 terlihat cut-off point index CD64 netrofil 1,49 mempunyai nilai sensitivitas 95,8\%,

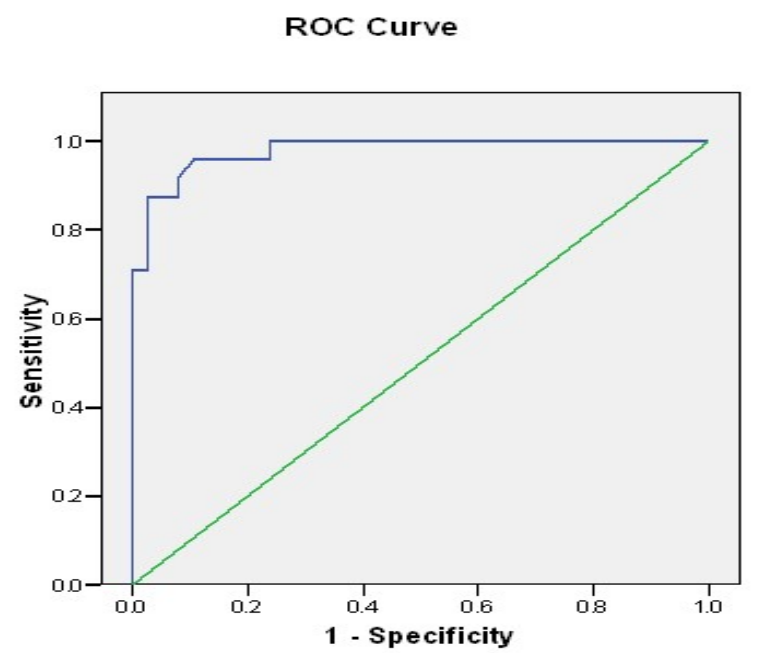

Gambar 1. kurva ROC (Receiver Operating Characteristic) dari CD64 netrofil

spesifisitas 76,3\%, nilai prediksi positif $71,8 \%$ dan nilai prediksi negatif $96,7 \%$.

\section{Pembahasan}

Penelitian ini dilakukan pada 62 anak yang menderita SIRS dengan jumlah anak laki-laki sama dengan perempuan, sesuai dengan penelitian epidemiologi yang tidak mendapatkan perbedaan jenis kelamin pada anak yang menderita SIRS. Carvalho $\mathrm{dkk}^{17}$ melakukan

Tabel 2. Rerata index CD64 netrofil pada awal masuk rumah sakit berdasarkan kultur bakteri darah

\begin{tabular}{lccc}
\hline Kultur bakteri darah & $\mathrm{f}(\mathrm{n}=62)$ & $\begin{array}{c}\text { Index CD64 netrofil } \\
\text { Rerata } \pm \text { SD }\end{array}$ & $\mathrm{p}^{*}$ \\
\hline Positif & 24 & $2,53 \pm 0,94$ & $<0,0001$ \\
Negatif & 38 & $1,21 \pm 0,34$ & \\
* $_{\text {t-test tidak berpasangan }}$ & & &
\end{tabular}

Tabel 3. Uji diagnostik CD64 netrofil dengan baku emas kultur bakteri darah

\begin{tabular}{lccc}
\hline CD64 netrofil & \multicolumn{2}{c}{ Kultur bakteri darah } & Total \\
\cline { 2 - 3 } & Positif & Negatif & \\
\hline Positif & 23 & 7 & 30 \\
Negatif & 1 & 31 & 32 \\
Total & 24 & 38 & 62 \\
\hline
\end{tabular}

Sensitifitas: 95,8\%; Spesifisitas: 81,6\%

NPP: 76,7\%; NPN: 96,9\% 
Herlina dkk: Uji diagnostik CD64 netrofil untuk sepsis pada anak dengan SIRS

Tabel 4. Uji diagnostik CD64 netrofil dengan cut-off point 1,49

\begin{tabular}{lccc}
\hline CD64 netrofil & \multicolumn{2}{c}{ Kultur bakteri darah } & Total \\
\cline { 2 - 3 } & Positif & Negatif & \\
\hline Positif & 23 & 9 & 32 \\
Negatif & 1 & 29 & 30 \\
Total & 24 & 38 & 62 \\
\hline
\end{tabular}

Sensitifitas: 95,8\%; Spesifisitas: 76,3\%

NPP: 71,8\%; NPN: 96,7\%

penelitian epidemiologi tentang prevalensi SIRS pada anak yang dirawat di ICU rumah sakit tersier di Brazil melaporkan 54\% pasien SIRS adalah berjenis kelamin laki-laki. Penelitian Pavare dkk, ${ }^{18}$ tentang prevalensi SIRS pada anak yang dirawat di the children's clinical university hospital di Latvia, juga melaporkan hal serupa (rasio perbandingan laki-laki dan perempuan 36/30). Pada kedua penelitian ini jumlah laki-laki lebih banyak dibandingkan perempuan, tetapi secara statistik tidak ditemukan perbedaan yang bermakna.

Pasien SIRS terbanyak pada penelitian ini adalah kelompok usia $>1-5$ tahun (43\%), diikuti kelompok usia 1 bulan -1 tahun (34\%). Hampir sama dengan penelitian yang dilakukan oleh Pavare $\mathrm{dkk}^{18}$ yang melaporkan bahwa kelompok usia terbanyak menderita SIRS pada anak adalah 2-5 tahun (39\%), diikuti oleh kelompok usia 1 bulan - 1 tahun (25\%).

Groselj-Grenc ${ }^{19}$ melaporkan bahwa CD64 netrofil mampu membedakan antara sepsis (SIRS infeksi) dan SIRS non infeksi lebih baik dari CRP (C-reactive protein) dan PCT (procalcitonin).Stubljar ${ }^{20}$ melaporkan bahwa CD64 netrofil merupakan satu-satunya biomarker yang negatif pada kasus SIRS non infeksi.

Rerata indeks CD64 netrofil pada kultur bakteri darah positif lebih tinggi dibandingkan dengan bakteri darah negatif. Di antara 62 pasien yang didiagnosis secara klinis menderita SIRS terdapat 24 (39\%) subjek dengan hasil kultur positif dan 38 (61,7\%) negatif. Indeks CD64 netrofil $\geq 1,5$ terdapat pada $30(48,4 \%)$ anak. Penetapan indeks CD64 netrofil untuk sepsis sebesar 1,5 (berdasarkan cut-offpointyang didapatkan oleh Grey). ${ }^{21}$ Didapatkan hasil sensitivitas 95,8\%, spesifisitas $81,6 \%$, NPP 76,7\%, dan NPN $96,9 \%$. Penelitian yang dilakukan oleh $\mathrm{Grey}^{21}$ dengan analisis kurva ROC (receiver operating characteristic) melaporkan bahwa indeks CD64 netrofil 1,5 bisa digunakan sebagai cut-off point untuk sepsis karena sudah menunjukkan adanya proses inflamasi karena infeksi sistemik.

Setelah dilakukan uji statistik, cut-off point indeks CD64 netrofil untuk menentukan sepsis adalah 1,49 dengan sensitivitas $95,8 \%$ dan spesifisitas $76,3 \%$. Nilai sensitifitas yang didapatkan sama bila dibandingkan dengan sensitifitas berdasarkan penetapan cut-off point 1,5, tetapi dengan spesifitas yang lebih rendah. Penelitian ini merupakan uji diagnostik yang lebih mengutamakan sensitifitas sehingga boleh saja mengambil cut off point 1,49 atau 1,5 untuk diagnosis sepsis. Icardi ${ }^{22}$ menggunakan cut-off point yang lebih kecil, yaitu 1,19 dengan sensitifitas 94,6\%, spesifisitas $88,7 \%$, nilai prediksi positif $89,8 \%$, dan nilai prediksi negatif $94 \%$. Penelitian Dhlamini ${ }^{23}$ menggunakan cutoff point 1,8 dengan nilai prediksi negatif yang tinggi, yaitu $95,2 \%$. $\mathrm{Cid}^{24}$ melakukan studi meta analisis tentang CD64, pada studi sepsis anak ditemukan rata-rata sensitifitas CD64 71\% dan spesifisitas 87\%. Studi meta analisis sepsis pada neonatus, anak, dan dewasa yang dilakukan oleh $\mathrm{Li}^{25}$ didapatkan sensitifitas CD64 netrofil 76\% dan spesifisitas $85 \%$. Allen ${ }^{11}$ melaporkan sensitifitas dan spesifisitas ekspresi CD64 pada netrofil untuk diagnosis infeksi sistemik 85\% dan $91 \%$. Berdasarkan beberapa penelitian tersebut terlihat sensitivitas dan spesifisitas yang bervariasi. Hal tersebut mungkin disebabkan oleh perbedaan kadar CD64 netrofil yang diambil untuk menetapkan sepsis.

Jumlah anak yang mengalami sepsis berdasarkan kultur bakteri darah positif adalah 24 (38,7\%) anak, lebih sedikit dibandingkan dengan jumlah anak dengan indeks CD64 netrofil $\geq 1,5$, yaitu $30(48,4 \%)$ anak. Pada penelitian ini dipakai BacT/ALERT Peds FA yang merupakan media biakan darah aerobik. BacT/ ALERT memiliki beberapa kelebihan, yaitu waktu deteksi mikroba yang lebih cepat dan spektrum deteksi mikroba yang lebih luas. ${ }^{26,27}$ Kultur darah dengan hasil positif hanya sedikit. Hal tersebut kemungkinan disebabkan karena sebelumnya pasien sudah ada yang 
mendapatkan terapi antibiotik sehingga memengaruhi hasil kultur darah. Sementara kadar CD64 netrofil tidak dipengaruhi oleh pemberian antibiotik sebelumnya. Hal tersebut menyebabkan adanya sampel dengan hasil CD64 netrofil positif, tetapi hasil kultur darah negatif.

Kelemahan penelitian ini tidak membedakan apakah pasien mendapatkan antibiotik sebelumnya atau tidak karena RS M. Djamil merupakan rumah sakit pusat rujukan sehingga umumnya pasien yang diterima sudah mendapatkan antibiotik sebelumnya. Dari hasil penelitian ini terlihat bahwa CD64 netrofil dapat menjadi salah satu biomarker yang dapat dipertimbangkan sebagai parameter diagnostik sepsis.

\section{Kesimpulan}

Nilai sensitivitas, spesifisitas, dan nilai prediksi negatif CD64 netrofil tinggi sehingga dapat digunakan untuk diagnosis awal sepsis pada penderita SIRS. Indeks CD64 netrofil 1,49 atau 1,5 dapat dijadikan sebagai penentu sepsis pada pasien SIRS. Disarankan untuk dilakukan pemeriksaan indeks CD64 netrofil pada setiap pasien SIRS untuk diagnosis dini sepsis sehingga terapi bisa diberikan lebih cepat dan dapat menghindari pemberian antibiotik yang tidak perlu.

\section{Daftar pustaka}

1. Latief A, Chairulfatah A, Alam A, dkk, Diagnosis dan tata laksana sepsis pada anak. Jakarta: UKK ERIA dan UKK Infeksi dan Penyakit Tropik IDAI;2016.

2. Singer M, Deutschman CS, Seymour CW, dkk. The Third International Consensus Definitions for Sepsis and Septic Shock (Sepsis-3). JAMA 2016;315:801-10.

3. Dewi R. Sepsis pada anak : pola kuman dan uji kepekaan. Maj Kedokt Indon 2011;61:101-6.

4. Souza D, Shieh HH, Troster EJ. Comparisons in the epidemiology and outcomes of pediatric septic patients admitted to public and private hospitals in Latin America. Pediatr Crit Care Med 2014;15:18-9.

5. Ruth A, McCracken CE, Fortenberry JD, dkk. Pediatric severe sepsis : current trends and outcomes from the pediatric health information systems database. Pediatr Crit Care Med 2014;15:828-38.

6. Weiss SL, Fitzgerald JC, Pappachan J, dkk. Global epidemiology of pediatric severe sepsis : the sepsis prevalence, outcomes, and therapies study. Am J Respir Crit Care Med 2015;191:1147-57.
7. Shime N, Kawasaki T, Saito O, dkk. Incidence and risk factors for mortality in paediatric severe sepsis : results from the national paediatric intensive care registry in Japan. Intensive Care Med 2012;38:1191-7.

8. Weiss SL, Fitzgerald JC, Balamuth F, dkk. Delayed antimicrobial therapy increases mortality and organ dysfunction duration in pediatric sepsis. Crit Care Med 2014;42:2409-17.

9. Venet F, Lepape A, Monneret G. Clinical review : flow citometry perspective in the ICU - from diagnosis of infection to monitoring of injury-induced immune dysfunctions. Crit Care 2011;231:1-9.

10. Khilnani P, Deopujari S, Carcillo J. Recent advances in sepsis and septic shock. Indian J Pediatr 2008;75:821-30.

11. Allen E, Bakke AC, Purtzer MZ, Deodhar A. Neutrophil CD64 expression : distinguishing acute inflammatory autoimmune disease from systemic infections. Ann Rheum Dis 2002;61:522-25.

12. Chan T, Gu F. Early diagnosis of sepsis using serum biomarkers. Expert Rev Mol Diagn 2011;11:487-96.

13. Marraro GA. Pediatric sepsis : actions to decrease sepsis in children. Expert Rev Anti Infect Ther 2009;7:941-4.

14. Livaditi O, Kotanidou A, Psarra A. Neutrophil CD64 expression and serum IL-8: sensitive early markers of severity and outcome in sepsis. Cytokine 2006;36:283-90.

15. Davis B. Improved diagnostic approaches to infection/sepsis detection. Expert Rev Mol Diagn 2005;5:193-207.

16. Hoffman JJ. Neutrophil CD64: a diagnostic marker for infection and sepsis. Clin Chem Lab Med 2009;47:903-16.

17. Carvalho PRA, Feldens L, Seitz EE, Rocha T, Soledade M, Trotta A. Prevalence of systemic inflammatory syndromes at a tertiary pediatric intensive care unit. J Pediatr 2005;81:143-48.

18. Pavare J, Grope I, Gardovska D. Prevalence of systemic inflammatory response syndroem (SIRS) in hospitalized children : a point prevalence study. BMC Pediatr 2009;9:25

19. Groselj-Grenj M, Ihan A, Derganc M. Neutrophil and monocyte CD64 and CD163 expression in critically ill neonates and children with sepsis : comparison of fluorescence intensities and calculated indexes. Hindawi Publish Corp Mediat Inflamm 2008;1:1-6.

20. Stubljar D, Skvarc M. Expression of CD64 on neutrophils can be used to predict the severity of bloodstream infection before broad range 16S rRNA PCR. Folia Microbiol 2014;1:1-8.

21. Grey D, Sack U, Scholz M, dkk. Increased CD64 expression on polymorphonuclear neutrophils indicates infectious complications following solid organ transplantation. Cytometry Part A 2011;79:446-60.

22. Icardi M, Erickson Y, Kilborn S, Stewart B, Grief B, Schamweber G. CD64 provides simple and predictive testing 
for detection and monitoring of sepsis and bacterial infection in hospital patients. J Clin Microbiol 2009;47:3914-9.

23. Dhlamini MB, Suchard MS, Wiggill TM, Fadahun OO, Ballot DE. Neutrophil CD64 has a high negative predictive value for exclusion of neonatal sepsis. South African J Child Health 2013;7:25-9.

24. Cid J, Aguinaco R, Sanchez R, Garcia-Pardo G, Liorente A. Neutrophil CD64 expression as marker of bacterial infection : a systematic review and meta analysis. Jof Infect 2010;60:313-9.

25. Li S, Huang X, Chen Z. Neutrophil CD64 expression as a biomarker in the early diagnosis of bacterial infection: a metaanalysis. Int J Infect Dis 2013;17:e12-23.

26. Mirrett S, Reller LB, Weinstein MP. Controlled clinical comparison of BacT/ALERT standard aerobic medium with BACTEC standard aerobic medium for culturing blood. J Clin Microbiol 2003;41:2391-4.

27. Horvath LL, George BJ, Hospenthal DR. Direct comparison of the BACTEC 9240 and BacT/ALERT 3D automated blood culture systems for candida growth detection. J Clin Microbiol 2004;42:115-8. 